\title{
СИСТЕМНО-БІОЛОГІЧНІ ТА СИСТЕМНО-МЕДИЧНІ УЯВЛЕННЯ ПРО ФУНКЦІОНУВАННЯ ОРГАНІЗМУ. ЧАСТИНА 1. УПОРЯДКУВАННЯ ТА СТРУКТУРУВАННЯ МЕДИЧНОЇ ІНФОРМАЦІї
}

О. П. Мінцер

\author{
Національна медична академія післядипломної освіти імені П. Л. Шупика
}

\begin{abstract}
Розглянуто принципи інформаційної впорядкованості. Підкреслюється думка, що без обґрунтування процесів упорядкування та структурування біологічної і медичної інсрормації домогтися підвищення її валідності неможливо. Останнє істотно ускладнить процедури створення електронної охорони здоров'я. Серед можливих шляхів розвитку системи медичної термінології звертається увага на використання онтології знань. Розглядаються також питання збереження раніше використаних і новостворюваних термінів. Робиться висновок про необхідність створення універсуму медичних знань.
\end{abstract}

Ключові слова: структурування інформації, упорядкування інформації, валідність інфрормації, термінознавство, термінополя, терміносистеми, інвентаризація термінів, унісрікація термінів, моно- і полісемантичність, онтологія медичних знань, універсум медичних знань.

\section{SYSTEM-BIOLOGICAL AND SYSTEM-MEDICAL NOTIONS ABOUT THE ORGANISM FUNCTIONING. PART 1. REGULATION AND STRUCTURING OF MEDICAL INFORMATION}

O. P. Mintser

\section{Shupyk National Medical Academy of Postgraduate Education}

Background. The principles of information orderliness are considered. It is emphasized that without substantiating the processes of ordering and structuring of biological and medical information, it is impossible to achieve an increase in its validity.

Results. The purpose of the study: substantiation of the conceptual approach to the systematization, streamlining and technology of creating a biological and medical terms systems.

The latter will significantly complicate the procedures for e-health creating. Among possible ways of the system development of medical terminology, attention is drawn to the knowledge ontology use. The issues of preserving previously used and newly created terms are also considered. It is concluded that there is a need to create an universum of medical knowledge.

Conclusions. 1. Several ways of creating an object terms systems are considered. The prospects of using ontologies are underlined. 2. The general scheme for constructing the universum of knowledge is given.

Key words: structuring of information, ordering of information, validity of information, terminology science, term's field, terms systems, terms inventory, terms unification, mono- and polysemantics, ontology of medical knowledge, universum of medical knowledge. 


\title{
СИСТЕМНО-БИОЛОГИЧЕСКИЕ И СИСТЕМНО-МЕДИЦИНСКИЕ ПРЕДСТАВЛЕНИЯ О ФУНКЦИОНИРОВАНИИ ОРГАНИЗМА. ЧАСТЬ. 1. УПОРЯДОЧЕНИЕ И СТРУКТУРИРОВАНИЕ МЕДИЦИНСКОЙ ИНФОРМАЦИИ
}

\author{
О. П. Минцер \\ Национальная медицинская академия последипломного образования имени П. Л. Шупика

\begin{abstract}
Рассмотрены принципы информационной упорядоченности. Подчеркивается мысль, что без обоснования процессов упорядочения и структурирования биологической и медицинской инорормации добиться повышения ее валидности невозможно. Последнее существенно усложнит процедуры создания электронного здравоохранения. Среди возможных путей развития системы медицинской терминологии обращается внимание на использование онтологии знаний. Рассматриваются также вопросы сохранения ранее использованных и вновь создаваемых терминов. Делается вывод о необходимости создания универсума медицинских знаний.
\end{abstract}

\begin{abstract}
Ключевые слова: структурирование информации, упорядочение иноормации, валидность иноормации, терминоведение, терминополе, терминосистемы, инвентаризация терминов, унификация терминов, моно- и полисемантичность, онтология медицинских знаний, универсум медицинских знаний.
\end{abstract}

Вступ. Метод пояснення помилок в аналізі медичної інформації, що вже став рутинним, грунтується на безперервному зростанні обсягів відомостей, одержуваних людиною, організацією, науковим або управляючим комплексом. Поступово прийшло розуміння того, що обчислювальна техніка та програмне забезпечення є лише допоміжним інструментом для вирішення саме інформаційних завдань.

Широке застосування обчислювальних засобів лише частково сприяє прискоренню оброблення та підвищенню точності. Можна припустити, що однією з найважливіших причин помилок у медичній практиці є збільшення інформаційної ентропії.

Спостерігається стрімке збільшення кількості стандартів, технологій і інструментів, спрямованих на роботу саме з інформацією і знаннями. Сюди відносяться завдання складного структурування інформації, використання різноманітних форм подання, витягання знань із «сирої» інформації, розподілений штучний інтелект і багато іншого [11, 23].

Абсолютно очевидно, що без обгрунтування процесів упорядкування та структурування інформації домогтися підвищення ії валідності неможливо. Тобто настав час серйозно замислитися про ефективну роботу безпосередньо з самою інформацією. Проте саме розуміння інформаційної упорядкованості й обгрунтованого структурування інформації у медичній галузі не очевидно [19-21]. У загальній теорії знань визначення впорядкованості інформації настільки багатопланове, що обговорення її на сторінках цієї статті практично неможливо. Воно пов’язане і з процесами ентропії, негентропії, теорії систем, енергії тощо.

Стосовно визначення впорядкованості інформації у біологічних і медичних системах, то серед ї̈ численних характеристик, що включають достовірність, точність, формалізованість, валідність та інші, знайти логіку порядку не $\epsilon$ можливим. Інша річ, коли розглядаються проблемні (задачні) побудови. Тоді з'являється й логіка порядку інформації.

Аналогічна проблема пов'язана $з$ питанням структуризації інформації. Точного визначення поняття «структурування» не існує, проте вважається, що найпростішим і ефективним способом поліпшення якості аналізу одержуваної інформації $€$ її структурування [23, 24].

Зауважимо, що в інформатиці під цим терміном розуміється розташування різних елементів інформаційного масиву та створення між ними таких зв'язків, щоб інформація краще сприймалася споживачами або цільовою аудиторією [22].

Сутність структурування інформації також визначається по-різному. Передбачається, що воно визначає розташування інформації у певному порядку, за певною схемою, наприклад, відповідно до хронології подій або від кодуючого елемента, який описує даний інформаційний блок [23].

Інтуїтивно можна припустити, що структурування в біології та медицині, де обсяги даних, що аналізуються, особливо великі, має виняткове значення.

Проте, відповідно до [22], «структурування медичних даних - це впорядкування масиву даних за заздалегідь заданим алгоритмом». Найбільш популярні три основні типи структурування даних: 
лінійний, ієрархічний і табличний. Для кожного з вказаних типів характерні свої принципи поділу даних і система адресації елементів. Лінійні, або спискові, структури даних складаються з простого переліку елементів даних. Подібну структуру, наприклад, має список пацієнтів, які перебувають у відділенні. Найчастіше цей список представляє собою журнал, де кожен пацієнт зареєстрований від рядка.

Мета дослідження: обгрунтування концептуального підходу до систематизації, упорядкування та технології створення біологічної і медичної терміносистеми.

Результати та їх обговорення. Спробуємо представити проблему з іншого боку. Принципово будь-яке впорядкування матеріалу починається з термінології. Зрозуміло, що і цей напрям потребує систематизації складових термінологічної роботи [24].

Відмінною рисою термінів звичайних слів є їхнє прикладне значення для предметних областей. Інакше кажучи, терміни призначені для відображення професійної діяльності людей і є компонентами певного професійного, наукового процесу. 3 іншого боку, будучи мовною одиницею, термін має семантичне навантаження. Функціонування та розвиток галузі вживання терміна грає важливу роль у його функціонуванні та розвитку. 3 цієї причини багато властивостей термінів і процеси їх формування, функціонування та розвитку визначаються екстралінгвістичними факторами. Відзначимо також, що значення терміна сильно залежить від рівня розвитку науки і техніки, предметної області та розвитку загального розуміння процесу. Важливо підкреслити, що зміст терміна у вузькій галузі не може правильно сприйматися в іншому напрямі знань [1].

Термінознавство — комплексна науково-прикладна дисципліна, що виникла на стику лінгвістики, логіки, семіотики, інформатики, загальної теорії систем і ряду предметних наук. У своєму розвитку термінознавство пройшло ряд природних етапів аж до формування власних методів і застосування їх у багатьох сферах науки, техніки, виробництва й управління. Відповідно до принципів цієї дисципліни введемо поняття терміносистеми, розуміючи під нею систему термінів у певній галузі, підгалузі наукового або технічного знання, що обслуговує наукову теорію або наукову концепцію $[14,17,18]$.

Наступним елементом впорядкування слід вважати уніфікацію терміносистеми мови, припускаючи, що до неї відносяться виконання нормативних вимог до термінів і, насамперед, інвентаризація. Під поняттям «інвентаризація» йдеться про збирання та тлумачення термінів, що відносяться до певної галузі знання, лексикографічного оброблення опису і відбору термінів. Результатом такої роботи є термінологічні словники [9].

У термінології зазвичай термін «уніфікація» розуміється як приведення до однаковості термінів, їх визначень тощо. «Уніфікація — це поширений i ефективний метод усунення зайвого різноманіття у вигляді скорочення переліку допустимих елементів і рішень, приведення їх до однотипності» [16]. Слід врахувати той факт, що при уніфікації термінів важливу роль відіграє й орієнтація терміна. Останнє безпосередньо пов'язано з питанням про внутрішню форму слова та виражає просту суму значень морфем, що складають слово, тобто буквальне значення слова, причому ступінь орієнтації показує наскільки повно експонент відображає ознаки сигніфікату (понятійний зміст імені) або денотату (позамовну дійсність) [5, 8, 9, 10].

Іноді розрізнити грань між уніфікацією та систематизацією дуже важко та навіть неможливо. Стандартизація будь-якої області термінології вимагає усунення всіх недоліків і формування єдиної системи термінів, що базується на однорідних принципах.

Важливо підкреслити, що питання термінології набувають особливого значення з урахуванням трансдисциплінарності, характерної сьогодні для сучасного розвитку суспільства взагалі, і науки зокрема. Так, розглядаючи бібліографознавство, треба відзначити, що в ньому досі немає точної, науково обгрунтованої терміносистеми.

Раніше наголошувалося, що основними вимогами до термінів є їхня однозначність і систематичність, тобто термін повинен позначати одне поняття та відображати об’єктивні зв'язки, що існують між відповідними поняттями. У бібліографічній термінології не завжди дотримуються названих вимог. Не зжиті полісемія та синонімія термінів, не досягнута стійкість у їхній системі.

Між термінологією, пропонованою загальною теорією бібліографії, та термінологією, що використовується в спеціальній бібліографії, не завжди спостерігаються єдність і взаємозв’язок як між загальними та спеціальними термінами, так і між термінами окремих видів спеціальної бібліографії. На жаль, досі в загальній і спеціальній термінології для позначення одного й того самого поняття 
вживаються різні терміни, та навпаки - в один і той самий термін вкладається різний зміст.

Передбачається, що наукова та навчальна література з загальної теорії бібліографії повинна відображати лише основні терміни. В спеціальній бібліографії можуть і повинні бути свої терміносистеми, але вони не повинні суперечити загальній системі основних термінів бібліографії. Проте, на тепер межі понять загальних і приватних, старих і нових термінів розмиті. Більш того, швидке оновлення терміносистем, поява нових наукових напрямів, міждисциплінарність і трансдисциплінарність науки та освіти вимагає нового підходу.

Терміносистема бібліографії в цілому повинна включати і загальне, й особливе: загальне, що є в терміносистемах кожного виду бібліографії, особливе, що є в кожній із них відповідно до специфіки галузі, а отже - i даного виду бібліографії. Іншими словами, необхідне створення постійного двостороннього зв'язку між спеціальною та загальною бібліографіями, що враховує вимоги кожної з них. Загальні бібліографічні терміни можуть зазнавати зміни при застосуванні в будь-якій конкретній сфері бібліографічної діяльності. I навпаки, особливості застосування цих термінів у спеціальній бібліографії повинні враховуватися при визначенні загальних термінів.

Створення термінологічного словника з бібліографії сприяло б формуванню єдиної терміносистеми галузі. Тому навіть із позначених позицій упорядкування бібліографічної термінології має бути пріоритетним напрямом наукових досліджень.

Термінам характерні однозначність, відсутність експресивності тощо. Рамки термінологізації встановлюються статистичними шляхами. В цьому процесі також немає єдиного розуміння. На думку ряду дослідників ступені термінологізації дозволяють виділяти крім термінів також і терміноїди, тобто лексичні одиниці, що ще не остаточно стали термінами. Визначаючи терміноїди як терміноподібні спеціальні лексичні одиниці, в роботі [6] вони називаються словами 3 нечітким статусом. Авторами розрізняються також терміноніми імена власні, що вживаються в спеціальному тексті, які виконують термінологічні функції або навіть $€$ терміноутворювальними лексичними одиницями [6]. Розібрати та визначити чіткий статус таких лексичних одиниць досить складно, але можливо при впорядкуванні термінів.

Украй неоднозначним видається співвідношення сенсу терміна та поняття когнітивності.
У «Короткому словнику когнітивних термінів» «поняття концепту відповідає уявленню про ті сенси, якими оперує людина в процесі мислення й які відображають зміст досвіду та знання, зміст результатів усієї людської діяльності та процесів пізнання світу у вигляді якихось «квантів» знання. Концепти повинні сприяти обробленню суб'єктивного досвіду шляхом підведення інформації під певні вироблені суспільством категорії і класи» [7]. Іншими словами, слід розглядати термін ще із змістовних позицій відносно міри вмісту в них концепту.

3і свого боку, з терміном «концепт» тісно пов'язаний і термін «семантичне поле», що пояснюється як сукупність слів і виразів, які утворюють тематичний ряд [2].

Стверджується, що конкретність, моносемантичність і лаконічність $€$ найважливішими рисами термінології. Однак у свідомості дійсність розділена на два взаємопов'язаних світи: матеріальний, матеріально відчутний світ і світ абстрактних понять і явищ. Відповідно, терміни повинні відображати ті ж самі світи. Проте існування кількох лексичних дублікатів термінів для одного й того самого поняття можна здійснити лише в разі заздалегідь передбачених правил, що доповнюються в процесі практичного використання термінологічних систем і аналізу методологічних помилок.

Для того щоб навести порядок у термінологічній лексиці, потрібний ряд операцій і процесів. Після їх реалізації можна досягти певного порядку та стандартних норм у термінології.

Логічний ярус уніфікації містить в собі рішення співвідношень терміна та поняття, визначення поняття в єдиній семантичній формі, виявлення понять, як елемента певної системи. Важлива частина цієї проблеми вирішується в процесі врегулювання термінології [22].

Нам представляється можливим спрощення процесу створення терміносистеми шляхом використання зорових і інших образів. Таке було раніше неможливим. Але розвиток обчислювальних технологій уже сьогодні, власне кажучи, дозволяє забезпечити ідентифікацію термінів на основі систем оброблення.

Інший можливий і ефективний шлях системного представлення знань ми пов'язуємо з використанням онтологій.

У серії наших досліджень [3, 12, 13, 15] онтологічна модель у своїй інформаційній основі мала механізм динамічного формування та використання 
ієрархій у вигляді певних таксономій і формально представлялась упорядкованою трійкою:

$$
O=\langle X, R, F\rangle \text {, }
$$

де X, R, F - кінцеві множини відповідно: X концептів (понять, термінів) предметної області, на основі яких формується предметна складова операційного середовища інформаційно-аналітичного супроводу; R - відношень та властивостей між ними (будемо вважати, що властивості є інтерпретацією відношень, тобто існує перетворення, яке кожному відношенню встановлює відповідність певної властивості); F - функцій інтерпретації (визначень) X та/або R, що складають функціональну частину операційного середовища інформаційно-аналітичного супроводу.

Певні труднощі з використанням термінів особливо в трансдисциплінарних уявленнях примусили більш глибоко вивчити лінгвістичні проблеми, зокрема питання створення семантичного поля. Раніше нами було показано [15], що в загальному випадку умова застосованості $t_{a p}\left(t_{a p}-\right.$ умова застосованості, вираз, що містить $n_{g}$ змінних) означає існування гомеоморфізму між орієнтованим графом, утвореним вхідною послідовністю лексем (а також синтаксичними зв'язками між ними), i певним еталонним орієнтованим графом $G_{a p}$, що представляє собою обраний користувачем підграф первинного представлення $T_{s n}{ }_{s n}$ певного тексту. В якості $T_{s n}$ може виступати первинне представлення як поточного тексту $T_{s n}$, так і будь-якого іншого тексту. Умова має певну структуру та складається з предикатів ідентифікації (розуміючи під предикатом його традиційне визначення як функції 3 множиною значень $\{0-$ неправда, 1 - істина $\}$ ), що визначена на заданій множині. Такі предикати дозволяють ідентифікувати контексти певної лексеми і на основі цього робити висновок про необхідність або відсутність необхідності виконання перетворення. Кожен із предикатів задає певну умову, а умовою застосовності правила $€$ виконання всіх умов, заданих кожним із предикатів. Кількість предикатів у виразі й задає число $n_{g}$.

$$
t_{a p}=c_{p_{1}}\left(x_{1}\right) \& \ldots c_{p_{n}}\left(x_{n_{g}}\right) \& r_{k_{11}}\left(x_{1}, x_{1}\right) \& \ldots r_{k_{n_{g} n_{g}}}\left(x_{n_{g}}, x_{n_{g}}\right)
$$

Одномісні предикати, присутні у виразі, - це предикати ідентифікації лексем. Такий предикат задає умову, якій повинна відповідати певна лексема (або конструкт) із вхідної множини.

Проте виявилися такі проблеми, що пов’язані зі швидкою появою нових лексем, нових термінів, нових зв’язків. 3 іншого боку, частина термінополя

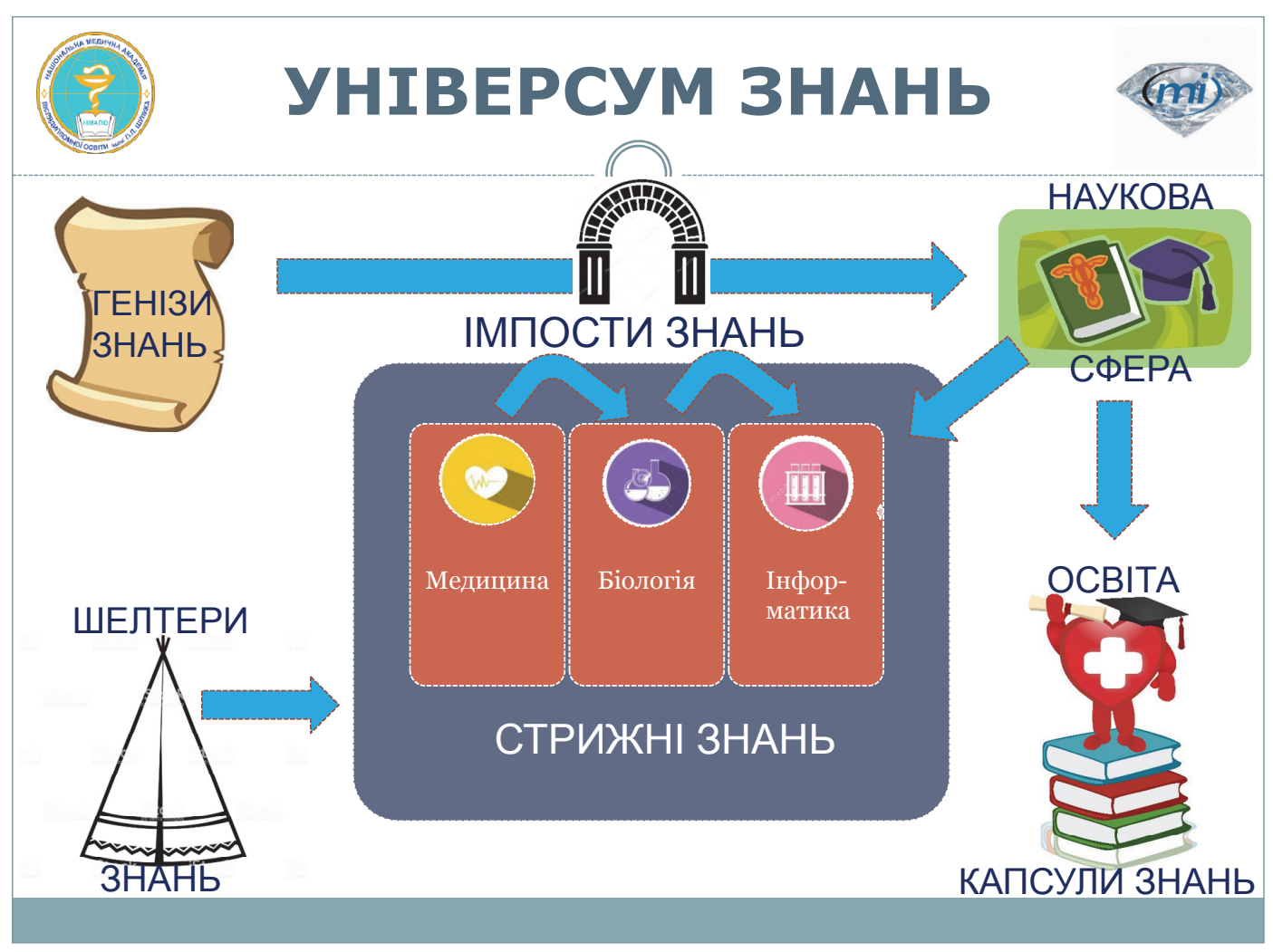

Рис. 1. Загальна схема універсуму знань 
використовується все рідше. Відповідно нами було поставлено завдання створення універсуму знань, під котрим ми розуміємо, як і в [4], сукупність об'єктів та явищ у цілому, що розглядається як єдина система. Деталі системних підходів, що використані нами, будуть надані в наступних частинах роботи. В цьому дослідженні сформулюємо лише загальну схему.

Виділено онтологію застарілих знань, що ми назвали генізою знань за аналогією з Каїрською генізою [25].

Застосовані також авторські семантичні деривати термінів. Розуміємо під шелтерами тимчасове сховище нових знань з новою термінологією, під

\section{Література.}

1. Авербух К. Я. Общая теория термина / К. Я. Авербух. - М. : Издательство МГОУ, 2006. - 252 с.

2. Белякова И. Г. Эволюция моделей межкультурной коммуникации в многоязычном пространстве глобального информационного общества / И. Г. Белякова. - Ногинск : Аналитика Родис, 2016. - 154 с.

3. Величко В. Ю. Деякі способи виділення відношень між термінами в природномовному тексті / В. Ю. Величко, В.В.Приходнюк // Системний аналіз та інформаційні технології : зб. наук. праць за матеріалами XV конференції (Київ, 27-31 травня 2013 р.). — К.: НТУУ «КПІ», 2013. - С. 406.

4. Дидье Ж. Универсум // Ж. Дидье. Философский словарь. Пер. с франц. - М. : Междунар. отношения, 2000. - 544 с.

5. Карасик В. И. Языковой круг: личность, концепты, дискурс / В. И. Карасик. - М. : Гнозис, 2004. — 477 c.

6. Кобрин Р. Ю. О понятиях «терминология» и «терминологическая система» / Р. Ю. Кобрин // История отечественного терминоведения: в 3-х т. / В. А. Татаринов. - М. : Московский Лицей, 2003. - Т. 3. Аспекты и отрасли терминологических исследований (1973-1993). - С. 35-40.

7. Краткий словарь когнитивных терминов / Е. С. Кубрякова, В. З. Демьянков, Л. Г. Лузина, Ю. Г. Панкрац; под общей редакцией Е. С. Кубряковой / - М.: Издательство МГУ, 1996. - 245 с.

8. Леонтович Е. А. О схеме, определяющей топологическую структуру разбиения на траектории / Е. А. Леонтович, А. Г. Майегр // ДАН СССР. - 1955. —T. 103, № 4. - С. 557-560.

9. Пашаева Г. Б. Основные принципы и меры унификации терминов / Г. Б. Пашаева // Гуманитарные научные исследования. - 2015. — № 4, Ч. 1. С. 137-143.

10. Ребрышкина И. А. Виды ориентации терминологических единиц / И. А. Ребрышкина, О. Л. Арискина імпостами — перехідні ланцюги знання в міждисциплінарних і трансдисциплінарних взаємовідносинах, а під капсулами знань - відносно постійні резервуари знань для завдань освіти. Загальна схема універсуму знань показана на рис. 1.

\section{Висновки.}

1. Розглянуто кілька шляхів створення предметної терміносистеми. Підкреслюється перспективність застосування онтологій.

2. Наведено загальну схему побудови універсуму знань.

// Научный журнал КУБГАУ. — 2011. — № 71 (07). - C. 1-9.

11. Семенов С. В. Информационное пространство как надстройка над распределенными системами / С. В. Семенов, И. А. Конюхов // Программные продукты и системы. — 2007. — № 1. - С. 56-57.

12. Стрижак А. Е. Инвариантные задачи онтологических систем / А. Е. Стрижак // Information technologies \& knowledge. - 2014. — №. 8. - C. 356-360.

13. Стрижак О. Є. Трансдисциплінарна інтеграція інформаційних ресурсів : дис. д-ра техн. наук : 05.13.06 / Стрижак Олександр Євгенійович. - К., 2014. - 470 c.

14. Тихонова И. Б. Когнитивное моделирование профессиональной терминосистемы: автореф. дис. ... канд. филол. наук : 10.02.04. - Омск, 2010. - 221 с.

15. Трансдисциплінарне представлення інформації за допомогою інтерактивних документів / О. П. Мінцер, В. В. Приходнюк, О. Є. Стрижак, О. М. Шевцова // Медична інформатика та інженерія. — 2018. — №1. - C. 47-52.

16. Тур О. Н. Унификация и стандартизация терминологии в сфере документально-коммуникационной деятельности общества / О. Н. Тур // Вестник ВГУ. Серия лингвистика и межкультурная коммуникация. — 2015. — № 1. - С. 48-52.

17. Шарафутдинова Н. С. О понятиях «терминология», «терминосистема» и «терминополе» / Н. С. Шарафутдинова // Филологические науки. Вопросы теории и практики. — 2016. — № 6, Ч. 3. - С. 168-171.

18. Шарафутдинова Н. С. Прагмонимы в специальной лексике по авиации (в русском, немецком и английском языках) / Н. С. Шарафутдинова // Филологические науки. Вопросы теории и практики. — 2016. — № 3 (57), Ч. 2. — С. 175-179.

19. Berwick D. M. MD on transitioning to value-based health care / D. M. Berwick // Healthc Financ Manage. — 2013. - Vol. 67, No. 5. - P. 56-59. 
20. Challenges of systematic reviewing integrative health care / I. Coulter, R. Khorsan, C. Crawford, A. F. Hsiao // Integr. Med. Insights. - 2013. - Vol. 8. - P. 19-28.

21. Costs of complementary and alternative medicine (CAM) and frequency of visits to CAM practitioners / R. L. Nahin, P. M. Barnes, B. J. Stussman, B. Bloom ; National Center for Health Statistics // National health statistics reports. - 2009. - No. 18.

22. Erteschik-Shir N. Information structure: the syntaxdiscourse interface / N. Erteschik-Shir. — Oxford : Oxford University Press, 2007. — 236 p.

23. Jones M. R. Structuration theory / M. R. Jones // Rethinking management information systems: an interdisciplinary perspective / Eds. W. L. Currie, R. D. Galliers. - Oxford University Press : Oxford, 1998.

24. Lambrecht K. Information structure and sentence form: topic focus and the mental representation of discourse referent / K. Lambrecht. — Cambridge : Cambridge University Press, 1994. - 338 p.

25. Reif S. C. Published material from the Cambridge Genizah collections: a bibliography, 1896-1980 / S. C. Reif. - Cambridge, 1988.

\section{References.}

1. Averbukh, K. Ya. (2006). Obshchaya teoriya termina [General theory of the term]. Moscow: Moscow State Regional University Publishing House. [In Russian].

2. Belyakova, I. G. (2016). Evolyutsiya modelei mezhkul'turnoi kommunikatsii v mnogoyazychnom prostranstve global'nogo informatsionnogo obshchestva [Evolution of models of intercultural communication in the multilingual space of the global information society]. Noginsk: Analitika Rodis. [In Russian].

3. Velichko, V. Yu., \& Prikhodnyuk, V. V. (2013). Deyaki sposobi vidilennya vidnoshen' mizh terminami $\mathrm{v}$ prirodnomovnomu teksti [Some ways to highlight the relationship between terms in a natural language text]. Sistemnii analiz ta informatsiini tekhnologii: proceedings on the materials of the XV conference) (Kyiv, 27-31 May 2013) (p. 406). Kyiv: NTUU KPI. [In Ukrainian].

4. Did'e, Zh. (2000). Universum. In Zh. Did'e. Filosofskii slovar' [Philosophy vocabulary]. Moscow: Mezhdunarodnye Otnosheniya (International Relationships). [In Russian].

5. Karasik, V. I. (2004). Yazykovoi krug: lichnost', kontsepty, diskurs [Language circle: personality, concepts, discourse]. Moscow: Gnozis. [In Russian].

6. Kobrin, R. Yu. (2003). O ponyatiyakh «terminologiya» $\mathrm{i}$ «terminologicheskaya sistema» [On the concepts of «terminology» and «terminological system»] In V. A. Tatarinov. Istoriya otechestvennogo terminovedeniya (History of Russian terminology), Vol. 3. Aspekty i otrasli terminologicheskikh issledovanii (Aspects and branches of terminology research) (1973-1993) (pp.
35-40). Moscow: Moskovskii Litsei (Moscow Lyceum). [In Russian].

7. Kubryakova, E. S., Dem’yankov, V. Z., Luzina, L. G., \& Pankrats, Yu. G. (1996). Kratkii slovar' kognitivnykh terminov [A brief dictionary of cognitive terms]. Moscow: MSU Publishing House. [In Russian].

8. Leontovich, E. A., \& Maiegr, A. G. (1955). O skheme, opredelyayushchei topologicheskuyu strukturu razbieniya na traektorii [On the scheme that determines the topological structure of a partition into a trajectory]. Reports of the Academy of Sciences of the USSR, 103(4), 557-560. [In Russian].

9. Pashaeva, G. B. (2015). Osnovnye printsipy i mery unifikatsii terminov [Basic principles and measures for the unification of terms]. Gumanitarnye nauchnye issledovaniya (Humanitarian research), 4(1), 137-143. [In Russian].

10. Rebryshkina, I. A., \& Ariskina, O. L. (2011). Vidy orientatsii terminologicheskikh edinits [Types of orientation of terminological units]. Nauchnyi zhurnal KUBGAU (Scientific Journal of KubSAU), 71(7), 1-9. [In Russian].

11. Semenov S. V., \& Konyukhov, I. A. (2007). Informatsionnoe prostranstvo kak nadstroika nad raspredelennymi sistemami [Information space as an add-on over distributed systems]. Programmnye produkty i sistemy (Software products and systems), 1, 56-57. [In Russian].

12. Strizhak, A. E. (2014). Invariantnye zadachi ontologicheskikh sistem [Invariant tasks of ontological systems]. Information technologies \& knowledge, 8, 356-360. [In Russian].

13. Strizhak, O. E. (2014). Transdistsiplinarna integratsiya informatsiinikh resursiv [Transdisciplinary integration of information resources]. (Doctoral dissertation). Kyiv. [In Ukrainian].

14. Tikhonova, I. B. (2010). Kognitivnoe modelirovanie professional'noi terminosistemy [Cognitive modeling of professional terminology]. (Candidate dissertation). Omsk. [In Russian].

15. Mintser, O. P., Prikhodnyuk, V. V., Strizhak, O. E., \& Shevtsova, O. M. (2018). Transdistsiplinarne predstavlennya informatsii za dopomogoyu interaktivnikh dokumentiv [Transdiscipline in the provision of information through interactive documents]. Medichna informatika ta inzheneriya (Medical Informatics \& Engineering), 1, 47-52. [In Ukrainian]. doi: http:// dx.doi.org/10.11603/mie.1996-1960.2018.1.8891.

16. Tur, O. N. (2015). Unifikatsiya i standartizatsiya terminologii v sfere dokumental'no-kommunikatsionnoi deyatel'nosti obshchestva [Unification and standardization of terminology in the field of documentary and communication activities of the society]. Vestnik VGU. Seriya lingvistika i mezhkul'turnaya kommunikatsiya (Bulletin of VSU. A series of linguistics and intercultural communication), 1, 48-52. [In Russian]. 
17. Sharafutdinova, N. S. (2016). O ponyatiyakh «terminologiya», «terminosistema» $\mathrm{i}$ «terminopole» [On the concepts of «terminology», «terminosystem», and «terminopolis»]. Filologicheskie nauki. Voprosy teorii i praktiki (Philological Sciences. Questions of theory and practice), 6(3), 168-171. [In Russian].

18. Sharafutdinova, N. S. (2016). Pragmonimy v spetsial'noi leksike po aviatsii (v russkom, nemetskom i angliiskom yazykakh) [Pragmons in the special lexicon on aviation (in Russian, German and English)]. Filologicheskie nauki. Voprosy teorii i praktiki (Philological Sciences. Questions of theory and practice), 3(57, Part 2), 175179. [In Russian].

19. Berwick, D. M. (2013). MD on transitioning to valuebased health care. Healthc Financ Manage, 67(5), 56-59.

20. Coulter, I., Khorsan, R., Crawford, C., \& Hsiao, A. F. (2013). Challenges of systematic reviewing integrative health care. Integr. Med. Insights, 8, 19-28. doi: 10.4137/IMI.S11570.
21. Nahin, R. L., Barnes, P. M., Stussman, B. J., \& Bloom, B. (2009). Costs of complementary and alternative medicine (CAM) and frequency of visits to CAM practitioners. National health statistics reports, 18. Hyattsville, MD: National Center for Health Statistics.

22. Erteschik-Shir, N. (2007). Information structure: the syntax-discourse interface. Oxford: Oxford University Press.

23. Jones, M. R. (1998). Structuration theory. In W. L. Currie, R. D. Galliers, Eds. Rethinking management information systems: an interdisciplinary perspective. Oxford University Press: Oxford.

24. Lambrecht, K. (1994). Information structure and sentence form: topic focus and the mental representation of discourse referent. Cambridge: Cambridge University Press.

25. Reif, S. C. (1988). Published material from the Cambridge Genizah collections: a bibliography, 18961980. Cambridge. 